\title{
OS FIGURINOS CARNAVALESCOS PARA A COMISSÃO DE FRENTE DO GRESE IMPÉRIO DA TIJUCA - 2011
}

Madson L. G. de Oliveira (UFRJ)

Suely M. Gerhardt (UVA)

Este artigo relata o processo de produção de figurinos carnavalescos da Comissão de Frente do GRESE Império da Tijuca, no Carnaval de 2011, que fez uma apresentação teatralizada, inspirada nos elementos formais e simbólicos do quadro A luta entre o Carnaval e a Quaresma, de Pieter Brueghel.

FIGURINOS CARNAVALESCOS, CARNAVAL, ESCOLAS DE SAMBA, PIETER BRUEGHEL, IMPÉRIO DA TIJUCA. 


\section{INTRODUÇÃO}

Nosso principal interesse neste trabalho é revelar como se dá o processo de confecção de fantasias para o carnaval, aqui denominadas figurinos carnavalescos, da Comissão de Frente do GRESE Império da Tijuca, no desfile de 2011.

As escolas de samba cariocas constituem grupos com hierarquias específicas e organizadas que se subdividem em presidência, diversas diretorias e cargos administrativos, como numa empresa. E o resultado dessa organização pode ser observado nos desfiles oficiais no período momesco.

Situadas em toda a região metropolitana do Rio de Janeiro e em diversos distritos e municípios, as escolas de samba cariocas englobam grande quantidade de pessoas envolvidas com o "saber carnavalesco" (GOLDWASSER, 1975, p. 174) na cidade do Rio de Janeiro, no período de outubro a fevereiro, que, com pouca variação, antecede seus desfiles oficiais.

Para observar este processo, utilizamos a Oficina de Carnaval realizada nos meses de janeiro e fevereiro de 2011 nas dependências da Universidade Veiga de Almeida UVA, como estudo de caso. Nessa ocasião, juntamos alunos e professores de moda, figurino e artes para confeccionar 15 figurinos carnavalescos que encenavam uma manifestação do carnaval, tendo como suporte o quadro do artista renascentista Pieter Brueghel $A$ luta entre o carnaval e a quaresma.

O referencial teórico para tratar, especificamente, o tema aqui proposto é embrionário, pois este relato busca contribuir com questões ainda pouco exploradas no universo carnavalesco, tendo por base o figurino como uma das áreas da arte. Alguns autores, entretanto, se preocuparam em estudar aspectos que tangenciam o objeto deste artigo, como a sociologia da arte, o carnaval carioca e os desfiles de escolas de samba. É a partir desses autores que buscamos o diálogo. Nessa perspectiva, nosso trabalho apresenta caráter interdisciplinar (SOMMERMAN, 2006) ao relacionar autores de campos que interagem e integram seus conceitos e procedimentos teóricos.

Entendemos que, a partir da multiplicidade dos autores selecionados, construímos a tessitura deste trabalho; sua base, no entanto, é de ordem social, e seu fundamento metodológico, o relato de experiência com observação participante.

Pretendemos, com este artigo, apresentar à comunidade acadêmica, através de manifestação cultural, artística e mercadológica, alguns aspectos da sociedade capazes de representar parte de uma população, além de revelar suas práticas, seus desejos e possibilidades de pensar os objetos produzidos como partes de suas vidas.

\section{PROPOSTA DE CONFECÇÃO DE FIGURINOS CARNAVALESCOS PARA O CARNAVAL DE 2011}

O carnaval do Rio de Janeiro não possui história única, pois seus autores são oriundos de várias vertentes que o constituíram. Dessa maneira, os grupos negros provenientes da Bahia, os imigrantes de várias regiões, as comunidades pobres cariocas, os ar- 
tesãos, artistas e músicos, bem como o povo que participava da festa carnavalesca reuniam-se em torno dos desfiles das escolas de samba, tornando-os em eventos urbanos que amadureceram, dos anos 30 aos anos 50, iniciando na década de 1960 sua trajetória rumo aos "desfiles-espetáculos" dos anos 80.

A história das escolas de samba está intimamente entrelaçada aos roteiros que seus desfiles seguiram na malha urbana carioca e também aos locais que foram utilizados - e não construídos para esse fim - para abrigar os barracões e ateliês ${ }^{1}$ em que eram - e até hoje ainda são - elaborados os elementos plástico-visuais de seus desfiles.

1. Barracão: local em que as alegorias e as fantasias são confeccionadas, antes do carnaval. Ateliê: espaço em que são confeccionadas as fantasias, e que podem estar dentro ou fora dos barracões.

A participação de artistas e profissionais oriundos de outras práticas que não o carnaval contribuiu para transformar os desfiles das escolas de samba em espaços híbridos, nos quais as diferentes experiências se juntaram para criar apresentações com forte apelo visual, através de alegorias, adereços e fantasias.

A década de 1980 foi decisiva para o novo carnaval, ${ }^{2}$ pois muitas mudanças foram efetivadas a partir da construção e inauguração de local específico para os desfiles das escolas de samba, em 1984, a Passarela do Samba, conhecida como sambódromo. A partir desse ano, a Liga Independente das Escolas de Samba do Rio de Janeiro - Liesa ${ }^{3}$ - passou a gerir o maior evento referente às escolas de samba: os desfiles. Essa entidade estabeleceu novas regras para a competição entre as agremiações, organizou o repasse de verbas do poder público e iniciativa privada para as escolas de samba, além de se responsabilizar pela venda dos ingressos para os desfiles no sambódromo.

As escolas de samba do Grupo Especial são julgadas de acordo com a proposta de seu desfile, em vários quesitos, por um grupo de jurados oriundos de diversas atividades e devidamente habilitados à função. Esses jurados são encarregados de avaliar dez itens nos desfiles das escolas de samba do Grupo Especial, a saber: comissão de frente, mestre-sala e porta-bandei-

2. O "novo carnaval", grifado aqui, distingue-se do "antigo carnaval" principalmente pelas dimensões trazidas pelo novo espaço e pela maneira como os desfiles passaram a ser organizados.

3. Associação dos dirigentes das principais escolas de samba do Grupo Especial que foi fundada, também em 1984, após dissidência de alguns de seus diretores da Associação das Escolas de Samba da Cidade do Rio de Janeiro (CAVALCANTI, 2009). ra, conjunto, bateria, alegorias e adereços, fantasias, enredo, harmonia, evolução e samba-enredo.

Para este trabalho, é importante esclarecer que os figurinos carnavalescos em questão destinam-se à comissão de frente de escola do Grupo de Acesso A. Esse grupo é organizado pela Liga das Escolas de Samba do Grupo de Acesso - Lesga desde 2009, quando houve dissidência da Associação das Escolas de Samba do Carnaval do Rio de Janeiro - AESCRJ, que ficou responsável também pelos Grupos de Acesso B, C, D e E (BARBIERI, 2010, p. 188). 
O desenvolvimento dos desfiles das escolas de samba se dá ao longo de vários meses de trabalho. Pudemos observar, através da participação em diversas agremiações carnavalescas, que o carnaval comumente é organizado em etapas (Quadro 1) que, com poucas variações, se repetem nas várias escolas de samba, pois todas seguem uma espécie de calendário contabilizando os dias que faltam para o desfile.

\begin{tabular}{|c|c|c|}
\hline \multicolumn{3}{|c|}{ Quadro 1 - Ciclo de produção dos desfiles das escolas de samba, no Grupo Especial } \\
\hline Etapa & Meses & Ação \\
\hline 1 & fev./mar. & Desfiles das escolas de samba \\
\hline 2 & abr./mai. & $\begin{array}{l}\text { Desmontagem das alegorias; reaproveitamento de materiais; } \\
\text { venda de esculturas para outras agremiações }\end{array}$ \\
\hline 3 & mai./jun. & $\begin{array}{l}\text { Contratação/recontratação de carnavalesco e outros profissio- } \\
\text { nais, como mestre de bateria, diretor de harmonia, etc.; eleição } \\
\text { de nova diretoria }\end{array}$ \\
\hline 4 & jun./jul. & Desenvolvimento do enredo \\
\hline 5 & jul./ago. & $\begin{array}{l}\text { Lançamento do enredo e desenho das fantasias e alegorias; defi- } \\
\text { nição do roteiro do desfile; entrega da sinopse do enredo para a } \\
\text { ala de compositores do samba-enredo }\end{array}$ \\
\hline 6 & ago./set. & $\begin{array}{l}\text { Confecção de peças-piloto ou protótipos a ser entregues aos dire- } \\
\text { tores de ala, para reprodução; ensaios nas quadras, com primeira } \\
\text { eliminação de sambas-enredos pré-selecionados; início de traba- } \\
\text { lhos para estruturação de alegorias (ferragem, marcenaria) }\end{array}$ \\
\hline 7 & out. & $\begin{array}{l}\text { Desfile de lançamento dos principais protótipos de fantasias; } \\
\text { escolha final do samba-enredo; início de trabalho de decoração } \\
\text { das alegorias (trabalho de bancadas) }\end{array}$ \\
\hline 8 & nov./dez. & $\begin{array}{l}\text { Confecção das fantasias de ala (nos barracões), de composição e } \\
\text { destaque (em ateliês externos); lançamento dos samba-enredos }\end{array}$ \\
\hline 9 & jan./fev. & $\begin{array}{l}\text { Finalização de decoração nas alegorias; finalização e entregas de } \\
\text { fantasias e adereços e, finalmente, preparação para o desfile }\end{array}$ \\
\hline
\end{tabular}

Com base no Quadro 1, podemos entender como se estrutura um desfile de escola de samba e como, quando e onde se dá a produção de seus figurinos. Os desfiles acontecem entre os meses de fevereiro e março (etapa 1), de acordo com o calendário oficial da Igreja católica (por conta da celebração da Semana Santa).

Após os desfiles e comemorações referentes à colocação de cada escola, há um período de descanso para as equipes fixas e a dispensa das equipes temporárias. As alegorias costumam ser desmontadas para guardar as peças que poderão ser aproveitadas (placas de acetato, esculturas, adereços, por exemplo), vendendo ou doando para outras escolas o que não servirá mais (etapa 2).

Nesse meio tempo, há uma espécie de jogo das cadeiras simbólico entre os diversos profissionais que mais se destacaram em suas agremiações. Como esses profissionais 
são autônomos e seu "passe" não é fixo, há negociação entre eles as escolas. Em alguns casos, os "contratos" são renovados; ${ }^{4}$ em outros, há substituição por outro profissional que esteja disponível ou que receba oferta melhor (etapa 3).

Logo após, o carnavalesco passa ao desenvolvimento do
4. Nem sempre há contrato oficial entre os profissionais e as escolas de samba; muitas vezes há apenas acordo verbal. enredo, para o qual toda a escola voltará seus esforços a fim de executar o projeto temático (etapa 4). Os enredos podem ter inspiração histórica ou fictícia, ou, ainda, homenagear figura pública, cultura/etnia, etc. Segundo Magalhães (1997), o enredo tem papel fundamental para o desenvolvimento de um desfile de escola de samba, sendo seu fio condutor nas várias fases desse processo (etapa 5) - é a partir dele que as alegorias e fantasias tomam forma.

Alguns carnavalescos apresentam em seus trabalhos aspectos projetuais, pois "após ter feito o projeto, o carnavalesco tem a chance de ver funcionando os vários setores, e se torna uma espécie de mestre de obras que acompanha a realização de suas ideias" (MAGALHÃES, 1997, p. 135). Podemos acrescentar à citação da carnavalesca, o sentido mais amplo de projeto, conforme Bomfim (1998, p. 162) descreve:

O projeto é a atividade onde informações de natureza abstrata serão transformadas em algo concreto - a forma. A esta atividade pertencem três tarefas principais: a organização de informações, a geração de conceitos e a apresentação de resultados.

Dessa maneira, entendemos como se dá a interdisciplinaridade no trabalho do carnavalesco que parece se mover numa linha imaginária, atravessando a arte e o design, em processos que levam em consideração os vários atores sociais responsáveis pelas tarefas indispensáveis à criação e ao desenvolvimento de um desfile de escola de samba. Entendemos que o trabalho desenvolvido por alguns carnavalescos se assemelha, em parte, tanto aos projetos elaborados por designers como ao trabalho de caráter artístico.

Outra abordagem dessa questão, apresentada por Velho (2006, apud SANTOS, 2009, p. 170), utiliza o conceito de Howard S. Becker para comparar o trabalho do carnaval ao trabalho artístico, já que é "sempre uma ação coletiva, em que diferentes indivíduos desempenham papéis específicos, em princípio complementares, embora nem sempre desprovidos de tensão e conflito".

Apesar da falsa impressão de homogeneidade nos desfiles das escolas de samba, percebemos que cada carnavalesco acaba desenvolvendo uma linguagem com códigos visuais bem marcados, diferenciando cada agremiação. Uma análise mais apurada do trabalho desses "artistas coletivos" e de seus "artesãos habilidosos" revela sua linguagem diferenciada e que se relaciona com uma infinidade de pessoas identificadas com suas escolas de preferência.

Essa identidade visual criada pelos carnavalescos pode ser entendida como aprimoramento nas linguagens desenvolvidas: seja por meio de novas técnicas, materiais ou visões diferenciadas, cada carnavalesco "escreve" também sua história e se "inscreve" na história das escolas de samba. Este misto de artista e designer, o carnavalesco, se cons- 
tituiu ao longo dos desfiles das escolas de samba, importando seu know-how das artes plásticas, dos espetáculos de teatro, da arquitetura e de outras origens que os tornam "clássicos", contemporâneos, contestadores, polêmicos, etc., conforme aponta o estudo de Becker (1977).

Nesse contexto, passamos para as fantasias, que são os objetos que vestem todos os brincantes, nos desfiles das escolas de samba; elas fazem parte do projeto visual iniciado com o desenvolvimento do enredo (etapa 05).

\section{FIGURINOS CARNAVALESCOS}

Para entendermos a importância das fantasias nos desfiles de escolas de samba, vejamos a classificação de seus elementos elaborada por Ferreira (1999, p. 105-106):

as fantasias para escola de samba têm elementos específicos e podem ser classificadas quanto 'aos patamares corporais', em: elementos apoiados na cabeça; elementos apoiados nos ombros; elementos apoiados na cintura; elementos apoiados no pescoço; elementos apoiados nos braços e pernas; elementos presos às mãos e elementos presos aos pés.

Dessa maneira, os integrantes das agremiações utilizam espécies de "próteses" que aumentam, vertical e horizontalmente, as alas a fim de "dar leitura" ao público, por conta da distância das arquibancadas, e reforçar o entendimento dos personagens e pontos-chave descritos nos enredos. As fantasias são compostas por chapéus, perucas, palas, ombreiras, colares, gravatões, anquinhas, escudos, braçadeiras, perneiras, sandálias, etc.

O projeto de figurinos é comumente realizado a partir de desenhos ou croquis, manuais ou digitalizados. Muitos carnavalescos contratam desenhistas e ilustradores profissionais para esse fim. $\mathrm{O}$ trabalho, mesmo sendo desenvolvido por um desenhista terceirizado, deve ser realizado em conjunto com o carnavalesco, já que a definição das siIhuetas, da cartela de cores e dos materiais é de sua responsabilidade. Cada vez mais, observamos que os projetos de fantasias são comprometidos em apresentar inovações estéticas, seja por meio da pesquisa de novos materiais ou substituição daqueles já utilizados por novas formas de expressão, como pinturas corporais, plumas sintéticas ou materiais reciclados, sempre com o intuito de comunicar-se com o grande público e o corpo de jurados, respeitando os conceitos apresentados no enredo. Esse processo é desenvolvido entre os meses de julho e agosto (etapa 05), para dar tempo de apresentar algumas fantasias à comunidade no desfile de protótipos, em setembro ou outubro (etapa 06). Além dessas fantasias, outras são também desenhadas e distribuídas para componentes de destaque, na escola.

As fantasias de alas ou grupos, geralmente em grandes quantidades (que variam de acordo com os setores de cada escola) são reproduzidas nos próprios barracões ou em ateliês externos a cada agremiação, em espécies de manufaturas prestadoras de serviços ou profissionais fixos contratados pela agremiação (etapa 08).

Os materiais utilizados na confecção de fantasias também parecem incomuns, pois, além dos tecidos e malhas, alguns carnavalescos utilizam acetatos, paetês, plumas, 
penas e aviamentos que servem para adereçar as fantasias. $O$ trabalho é muito rebuscado, pois, apesar de alguns aviamentos e bordados serem comprados a metro, industrializados ou manufaturados em oficinas especializadas, o modo de aplicação é, muitas vezes, manual, ressaltando, assim, o caráter artesanal.

Observamos que as fantasias carnavalescas produzidas para vestir os brincantes geram trabalho e incrementam o comércio (etapa 08). Algumas áreas nesse segmento criam modos de produção inusitados ou adaptam os saberes de outras áreas, como a utilização de placas de acetato batidas em máquina de Vacuum Forming, desenvolvida exclusivamente para esse fim.

As fantasias prontas não revelam a grande quantidade de etapas que antecedem os desfiles, como o desenho de croquis, a compra de materiais, a confecção de protótipos e a reprodução das fantasias. Tudo isso de uma forma que alia o modo artesanal com a ajuda de alguns processos manufatureiros ou de design, como costura, pistola de cola quente, soldas, placas de acetato, etc.

Os elementos plástico-visuais dos desfiles das escolas de samba funcionam como uma espécie de sintaxe que comunica as informações principais desenvolvidas no enredo. Esses figurinos carnavalescos, ou fantasias, "escrevem" visualmente as partes da história, que deve ser compreendida pelos que assistem aos desfiles. Essa "escrita visual" é o que possibilita a definição das assinaturas dos carnavalescos e o status como artistas modernos ou designers de uma prática ainda por se estabelecer.

Dessa maneira, podemos perceber que a função do carnavalesco em uma escola de samba demonstra "como certos indivíduos no mundo do carnaval carioca funcionariam como ponto de confluência de algumas 'tensões e relações'", conforme demonstrou Santos (2009, p. 160). Entendemos o trabalho realizado pelos carnavalescos atuais em parte como arte, em parte como design e, por isso, podemos estudar os figurinos carnavalescos simultaneamente como processo e produto de "novas formas de design".

Assim, os figurinos produzidos pelo (e para o) carnaval devem ser entendidos como produtos de um tecido social. As fantasias demonstram uma produção, no âmbito das escolas de samba, que mistura modos de operação, bem como se assimilam às ações de design (através dos projetos e processos sistematizados.

\section{O PROCESSO DE CRIAÇÃO E CONFECÇÃO DOS FIGURINOS CARNAVALESCOS DO GRESE IMPÉRIO DA TIJUCA 2011 INSPIRADOS NO QUADRO A LUTA ENTRE O CARNAVAL E A QUARESMA}

O carnavalesco Severo Luzardo, responsável pelo enredo "O mundo em carnaval - um olhar sobre a cultura dos povos", do GRESE Império da Tijuca, já trabalha com a criação de projetos carnavalescos e figurinos para produções televisivas há alguns anos. Em sua prática, antes da execução do projeto, há sempre um período de pesquisa. Para 2011, o carnavalesco utilizou a obra de Brueghel para ilustrar o início do desfile de sua escola de samba, vestindo a comissão de frente com roupas de época. A escolha desse 
trabalho de Brueghel faz referência ao tema "Carnaval verso Quaresma”, desde antigos tempos, como um subtema desenvolvido pelo carnavalesco. Ele se baseou no período renascentista, nas formas e cores dos personagens principais do quadro de Brueghel, tanto pela temática quanto pelos elementos simbólicos nele contidos.

5. Composta de figurinistas, alunos e ex-alunos de moda e de outros cursos que atuam junto à Pósgraduação em Figurino e Carnaval da Universidade Veiga de Almeida - UVA.
A partir dessas primeiras informações, uma equipe de trabalho ${ }^{5}$, trabalhando sobre nossa coordenação passou à confecção dos figurinos propostos pelo carnavalesco. Assim, temos a oportunidade de revelar como os conteúdos de arte, moda e carnaval interagem entre si, e, além disso, como esses conteúdos podem (e devem) ser usados na prática profissional, seja no caso de figurinistas ou criadores de moda.

Os figurinos carnavalescos para essa proposta contemplam as roupas, os adereços (chapéus e adornos) e os sapatos. Antes de passarmos a seus detalhes, porém, cabe contextualização do artista e da obra que serviu de inspiração ao projeto.

\section{A ARTE DE BRUEGHEL E A INSPIRAÇÃO PARA A COMISSÃO DE FRENTE}

Expressão comum ao universo do carnaval, embora talvez não para as demais pessoas, comissão de frente é um grupo de brincantes que faz parte do desfile das escolas de samba, e cuja fundamental importância está no fato de ser encarregada de "abrir" o desfile de cada agremiação carnavalesca. As duas principais funções das comissões de frente são concomitantes: pedir passagem para os demais integrantes da escola e apresentar seu enredo. Geralmente, as comissões de frente são compostas por grupo que costuma ter entre 11 e 15 pessoas.

Atualmente, as comissões de frente têm desempenhado papel quase dramatúrgico no sentido de encenar os pontos mais relevantes do enredo desenvolvido pelo carnavalesco e materializado através dos movimentos de dança e plasticidade de seus figurinos e adereços. No início dos desfiles das escolas de samba não era assim, como revela Farias (2009, p. 15) ao descrever historicamente a importância desses grupos ao longo do século XX:

A comissão de frente, na fase de estruturação das Escolas de Samba, era composta pelos veneráveis da Escola e por integrantes da comunidade, pessoas que eram a síntese de sua ancestralidade e resistência, a verdadeira história da agremiação. Com o tempo, foi necessário que ela passasse por modificações para se inserir ao contexto contemporâneo de apresentação das Escolas, em que prima pelo visual, pela criatividade e, principalmente, pela inovação.

Passamos, agora, ao esclarecimento de como "penetramos" a pintura e o universo de Brueghel para chegar ao carnaval, do passado e do presente.

Pieter Brueghel é originário dos Países Baixos e viveu durante o período conhecido como Renascimento. Muitos são os escritos sobre esse artista e sua trajetória. $\mathrm{O}$ VeIho, como era chamado Pieter Brueghel, nasceu por volta de 1525, em Flandres, na Bél- 


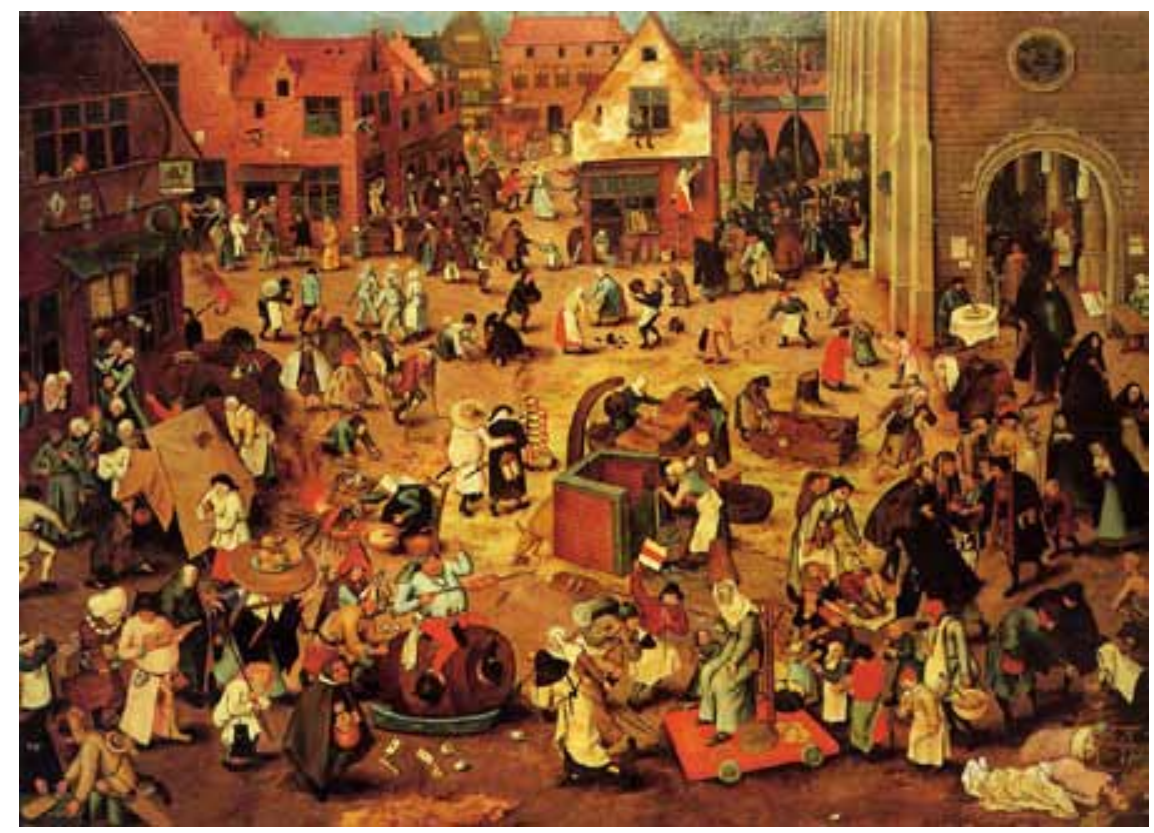

Figura 1: A luta entre o Carnaval e a Quaresma, Pieter Brueghel Fonte: Civita, 1978.

gica e morreu por volta de 1569. Durante esse pouco tempo de vida, o artista deixou inúmeras obras fantásticas (CIVITA, 1987, p. 6).

O conturbado momento histórico em que viveu e as divergências religiosas entre a Holanda protestante e a Espanha católica propiciaram a criação de obra particularmente rica em contrastes e detalhes.

Em seu quadro A luta entre o carnaval e a quaresma, observamos a representação de uma cena festiva na aldeia, com os costumes que marcavam o final da Quaresma, período do calendário cristão que se inicia na Quarta-feira de Cinzas e termina no Domingo de Páscoa, coincidindo com a Ressurreição de Cristo. Durante esse período, é proibido qualquer tipo de excesso, exigindo-se dos fiéis abstenção completa.

Nessa obra há flagrante metáfora que divide o homem cristão ao meio: envolto em questões religiosas que o colocam entre o sagrado e o profano; entre as tentações dos prazeres e a promessa de moderação.

Na Figura 1, observamos em meio à grande quantidade de elementos do quadro usado como referência para a confecção dos figurinos carnavalescos as silhuetas dos personagens principais: Carnaval e Quaresma.

O carnaval é representado por figura masculina, profana e gorda, em clara referência ao pecado da gula que a falta de moderação propicia. E a Quaresma, por silhueta feminina e religiosa. Desse quadro podemos, ainda, destacar alguns elementos importan- 
tes para nosso trabalho, como a temática e as cores. O tema, por si só, parece pertinente, pois a "luta/batalha" põe em oposição dois principais grupos de pessoas liderados pelos personagens principais. É interessante perceber como esses grupos populares que integram a festividade se assemelham ao carnaval contemporâneo de rua; o artista os representou quase como em um instantâneo fotográfico da época.

\section{OS FIGURINOS PARA A COMISSÃO DE FRENTE “CARNAVAL E QUARESMA"}

Conforme já mencionado, o projeto plástico-visual de enredos carnavalescos pressupõe pesquisa de formas, cores, texturas, etc. No caso específico dessa comissão de frente, o carnavalesco Severo Luzardo nos apresentou uma seleção de imagens associadas ao tema do quadro de Brueghel. Não havia, portanto, um projeto fechado, nem os croquis definitivos, como é comum nas demais alas.

Houve uma concepção coletiva, tanto nas formas quanto na seleção do material a ser empregado. Apesar de não haver projeto definitivo, o carnavalesco deixou bem claro o que gostaria de ver como representação de sua comissão de frente. E definiu os personagens principais, trouxe algumas peças de figurinos de outras produções e deu o tom de sua própria representação daquele grupo de bailarinos.

Na definição de Severo, os personagens principais - Sr. Carnaval e D. Quaresma -

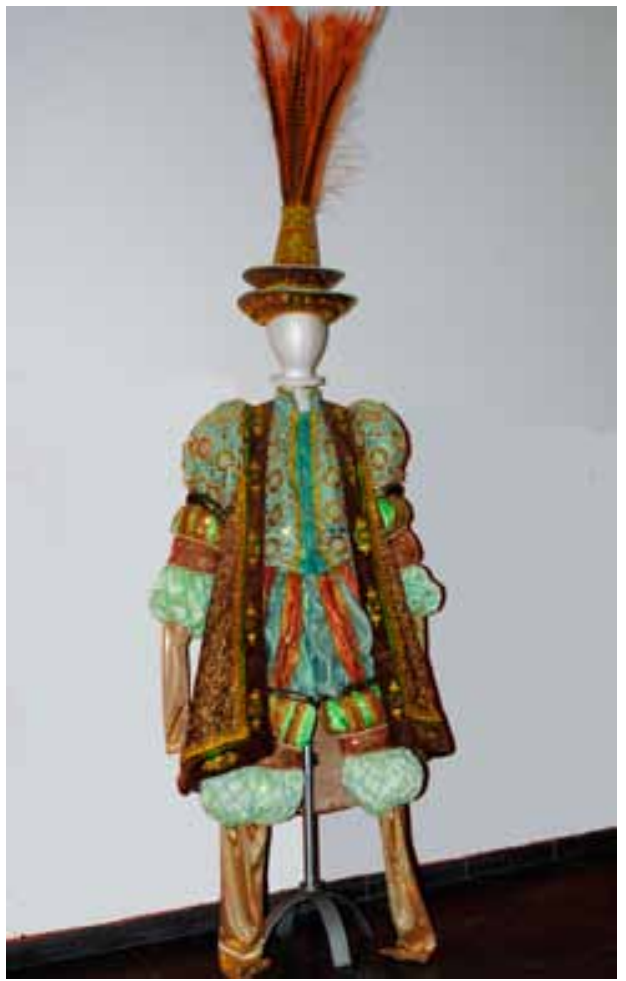
são ladeados pelo "povo". Como a comissão de frente pode conter no máximo 15 componentes e para que esse grupo pudesse "encenar" a bataIha carnavalesca, acrescentamos outros personagens para compor a cena. Além do Sr. Carnaval e de D. Quaresma, introduzimos a figura do Coringa, como personagem que atiça a rivalidade dos oponentes. Colocamos quatro figuras, simultaneamente guardiões e bobos do Sr. Carnaval. Adicionamos a esse grupo três casais de nobres, fazendo menção à corte momesca, e, para finalizar, uma mulher representando o "povo".

Figura 2: Figurino completo e finalizado do Sr. Carnaval Fonte: Mayra Castro e Priscilla Baetá. 
É importante alertar que os figurinos carnavalescos, no caso da comissão de frente, devem vestir os bailarinos e contribuir para os movimentos de suas coreografias. Portanto, há especial cuidado para que os figurinos não atrapalhem e possam tornar seus brincantes críveis em seus respectivos personagens, assim como no teatro.

Na Figura 2, mostramos o personagem. Nele, Optamos por "engordar" o Sr. Carnaval, utilizando o recurso de mangas e calção bufantes, características também da indumentária renascentista. Utilizamos o verde-turquesa como cor de base para o figurino e o combinamos com tons terrosos, como bronze e ouro velho. Observamos que o colete verde é feito com o tecido próprio do mercado carnavalesco chamado de lamê irisado. A fim de "rebaixar" o tom muito vivo do verde, usamos um tecido telado e bordado em dourado, com motivos geométricos, para sobrepor o tom do casaco. Empregamos o mesmo tecido verde do colete no forro do calção, e aplicamos lamê cobre em tiras adereçadas com galões dourados e paetês verdes. Esse processo se repetiu nas mangas da capa em tecido dévoré marrom. A escolha da cor verde faz referência a uma das cores da Escola de Samba Império da Tijuca, mas em tonalidade mais baixa do que a usada no paviIhão da agremiação. Tanto no colete quanto na capa nossa principal intenção foi utilizar algumas cores do quadro de Brueghel, além de contrastar com a cor do figurino de sua oponente, D. Quaresma. Finalizando o figurino do Sr. Carnaval, chamamos atenção para o adereço de cabeça, que teve sua estrutura feita em papel couro e revestida com os tecidos já descritos no figurino e finalizada com penas de pavão e faisão tingidas em tons acobreados.

\section{Quaresma (Figura 3)}

foi representada com figurino em duas peças: corselet e saia. Esta siIhueta é própria do final do Renascimento: cintura bem apertada (pelo uso do corselet) e contrastando com o volume da saia (afastada do corpo pelo uso de enchimentos), conforme Laver (1989) e Köhler (1989). Na saia, há sobreposição de renda preta e dourada ao tecido com relevo texturizado (jacquard) violeta com motivos religiosos. Essa sobreposição forma uma

Figura 3: Figurino completo e finalizado de D. Quaresma Fonte: Mayra Castro e Priscilla Baetá.

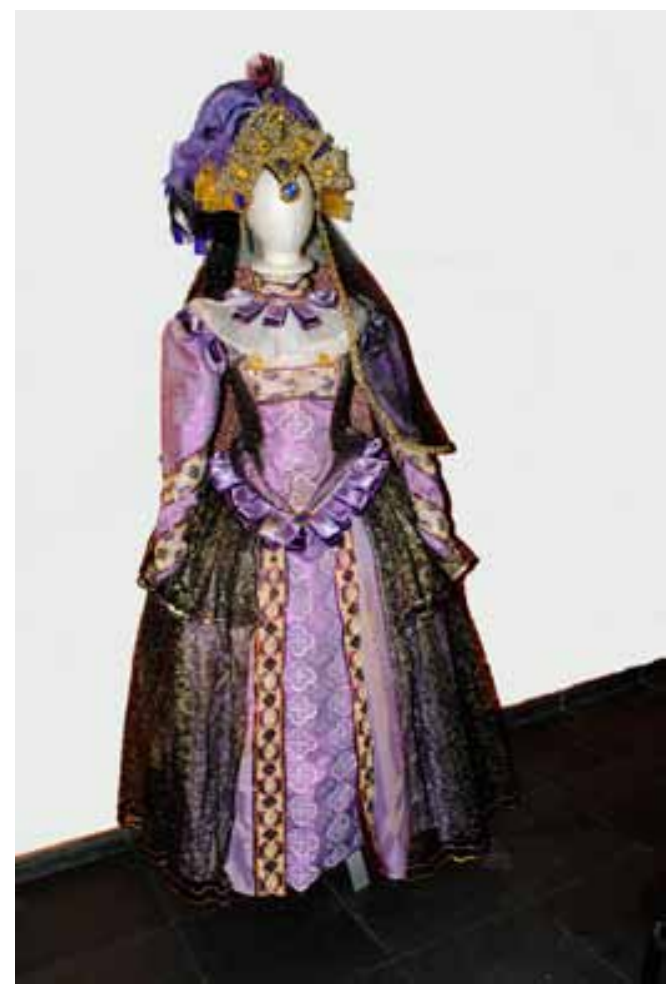




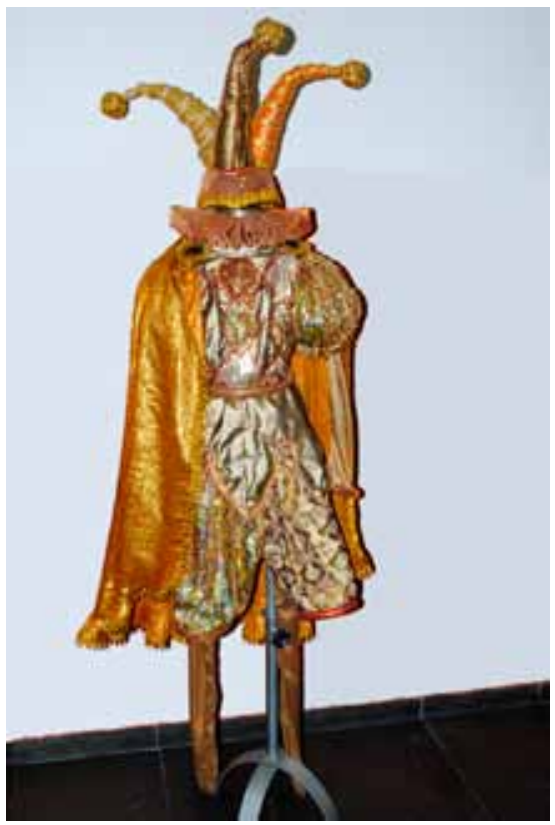

Figura 4: Figurino completo e finalizado do personagem Coringa

Fonte: Mayra Castro e Priscilla Baetá.

espécie de "V" invertido que remete à indumentária espanhola, também por conta da sobriedade do preto, comum àquela localidade. A seleção de cores desse figurino referencia-se ainda no imaginário que fazemos sobre sua simbologia religiosa, quando destacamos os tons arroxeados e violáceos, próprios da Igreja católica durante o período da Quaresma. Outros detaIhes confirmam o recato da representação da figura de D. Quaresma, como as mangas compridas e a gola alta e armada, conhecida como rufo. Para a cabeça, uma armação de arame foi recoberta com tecidos e telados dourados, enfeitados com pedras, paetês e plumas roxas. Há, ainda, um véu telado preto até a altura da cintura, representando mantilha religiosa.

O personagem Coringa (Figura 4) reforça a encenação da batalha entre o Sr. Carnaval e D. Quaresma. Seu figurino é composto por capa presa ao gibão - casaco renascentista, segundo Sabino (2007, p. 289) -, calção com meias ajustadas às pernas, geralmente, usadas por baixo do calção (leggings) e um grande e pontudo adereço de cabeça. Os tons utilizados foram os dourados e acobreados, com tecidos diferentes formando um brilhante patchwork. Todo o figurino apresenta assimetria, como nas mangas bufantes diferentes e nas pernas do calção pouco bufantes. O corpo do gibão é decorado com losân-

Figura 5: Grupo de quatro figurinos finalizados e completos dos guardiões Fonte: Mayra Castro e Priscilla Baetá.

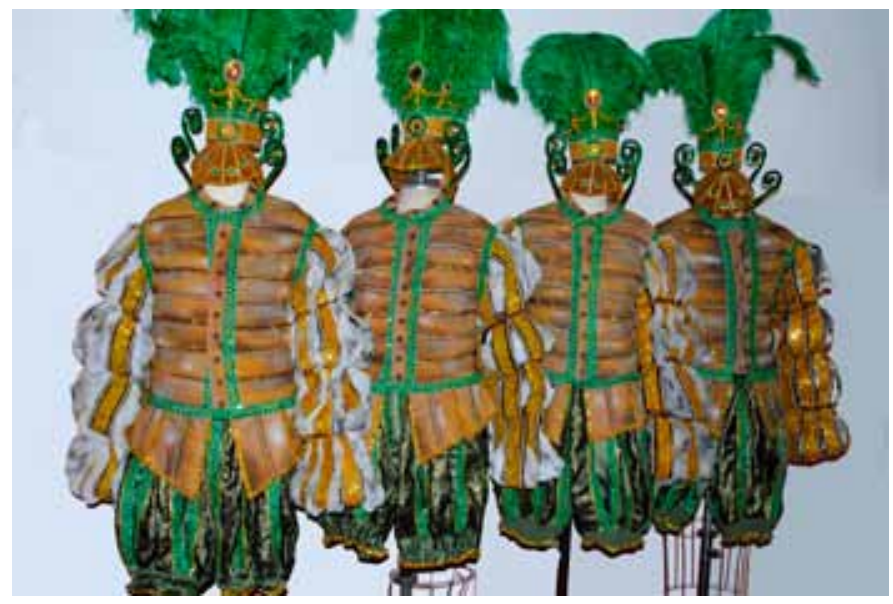




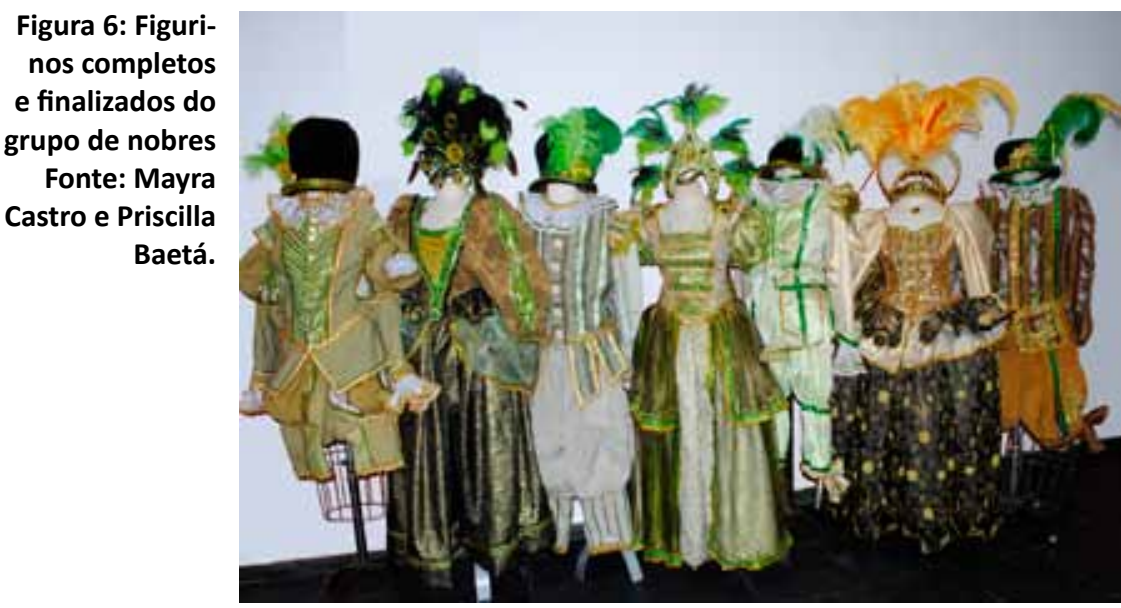

gulos, em referência a outro personagem da commedia dell'arte, o arlequim. No pescoço, farto rufo, armado com tecido em lamê cobre. Na cabeça, chapéu com três cones finalizados com bolas, imitando os guizos, próprios dos bobos da corte medievais.

Os quatro bailarinos (Figura 5) que interpretam os guardiões do Sr. Carnaval vestem figurinos idênticos, compostos pelo doublet $^{6}$ de mangas múltiplas vezes bufantes e calções também bufantes. Na cabeça aramada, um grande penacho de plumas verdes simboliza a cavalaria de reinados antigos. As cores usadas

6. Doublet: gibão acolchoado e justo usado por cima da camisa de gola alta. nesses figurinos são basicamente misturas de tons terrosos do doublet ocre com verdes-escuros dos calções e enfeites em toda a roupa associados ao amarelo e dourado. Nesse caso especificamente, o carnavalesco (re)aproveitou parte do figurino trazido de outras produções, como maneira de reciclar peça de roupa que já não tinha mais utilidade, ancorada em acervo.

O grupo seguinte (Figura 6) compõe-se dos três casais mais um nobre que acompanham D. Quaresma e, pela proximidade de sua posição social, ladeiam a Igreja católica.

São trajes que, de alguma maneira, repetem as silhuetas masculina e feminina até então mostradas, do Sr. Carnaval e de D. Quaresma, dessa vez menos imponentes e chamativas. As roupas femininas, em sua maioria, são compostas por corselets apertados e saias amplas, em cores "neutras", como bege, dourado velho e verdes distintos, referindo-se à palheta de cores da própria escola de samba. Nos figurinos masculinos desse grupo, usamos o mesmo recurso do descrito anteriormente, em tons pastéis de verde, ocre e marrom, devidamente pontuados com cores mais "vivas" para dar o desejado contraste. Tanto nos trajes masculinos quanto nos femininos, há uma infinidade de passamanarias enfeitando e carnavalizando tudo, pois mesmo se tratando de figurino a função dessas peças é representar o carnaval.

Finalizando a descrição dessa comissão de frente, a mulher (Figura 7) que representa o povo: menos elaborada nos detalhes e acabamentos, mais sóbria na seleção de 
7. Contamos com duas equipes distintas para a realização dos figurinos dessa comissão de frente. A primeira era composta por modelistas, cortadores e costureiras; a segunda, basicamente, por aderecistas. Para o trabaIho de modelagem, corte e costura foram contratados prestadores de serviços, "importados" do campo da moda e figurino teatral. No entanto, a segunda equipe, de aderecistas, foi formada por alunos previamente selecionados, de acordo com suas habilidades $e$ aptidões; alunos tanto do campo da moda quanto da área de figurinos que estão em seu processo de formação e fizeram do atelier de carnaval um "laboratório" experimental. Entendemos que tanto nas artes quanto no figurino, a formação é de cunho teóricoprático, sendo a prática a tônica da profissão, pois o "fazer" é que possibilita aprendizado que ultrapassa a sala de aula. Seja na utilização de processos estudados em aulas teóricas, seja no improviso da utilização de materiais inusitados (como é o caso do carnaval), percebemos o olhar de encantamento quando cada aluno consegue materializar seus desejos em adereços $e$ peças desse figurino. cores e materiais. Os tecidos, lisos e estampados, não brilham, e seu adereçamento é feito com pequenos fuxicos de tecidos. A diferença maior entre esse traje e os dos personagens da corte é o avental, que a identifica como serva. O verde, muito claro, usado nesse figurino refere-se à cor já desbotada, dessa vez associada à padronagem estampada.

Todos os figurinos são acrescidos de paetês a metro, gaIões, torçais de seda, grelôs, rendas metálicas e plumas, complementando nosso trabalho.

Todo o processo de confecção dos figurinos passou pela modelagem das peças, corte nos tecidos, costura e, finalmente, adereçamento. $^{7}$

\section{CONCLUSÃO}

Este artigo buscou descrever e analisar o processo de confecção dos figurinos carnavalescos realizados para uma comissão de frente tendo por base o quadro $A$ luta entre o carnaval e a quaresma, do artista renascentista Pieter Brueghel. A produção dos figurinos carnavalescos revela muito sobre quem os realiza, onde são feitos, permitindo a sobrevivência de parte da sociedade brasileira, como fenômeno de identidade cultural. Além disso, parece-nos que a produção dessas fantasias carnavalescas supre "uma necessidade" de dar realce a quem os veste, ao levar consigo um pouco da arte e do tema tratado pelo artista Pieter Brueghel, em sua cena de batalha que, em alguma medida, espelha a própria festa carnavalesca contemporânea.

Ferreira (1999, p. 115) reforça a ideia de que o profissional responsável pelos figurinos das escolas de samba, até meados do século $X X$, era oriundo de outras práticas em que contava com a habilidade manual e foi só a partir da década de 1960, com a chegada de artistas da academia, que essa situação passou por modificações que vemos refletidas em nosso trabalho.

Magalhães (1997, p. 52), no entanto, revela que, com o passar do tempo, a semelhança entre os figurinos de carnaval e aqueles desenvolvidos para as produções teatrais pode ser observada no processo de ensino/aprendizagem da oficina de carnaval, na Universidade.

Essa constatação nos leva para um ponto a ser destacado neste trabalho: os figurinos e outras produções desse tipo, atualmente, parecem se encontrar "em aberto" ou em "transição" 


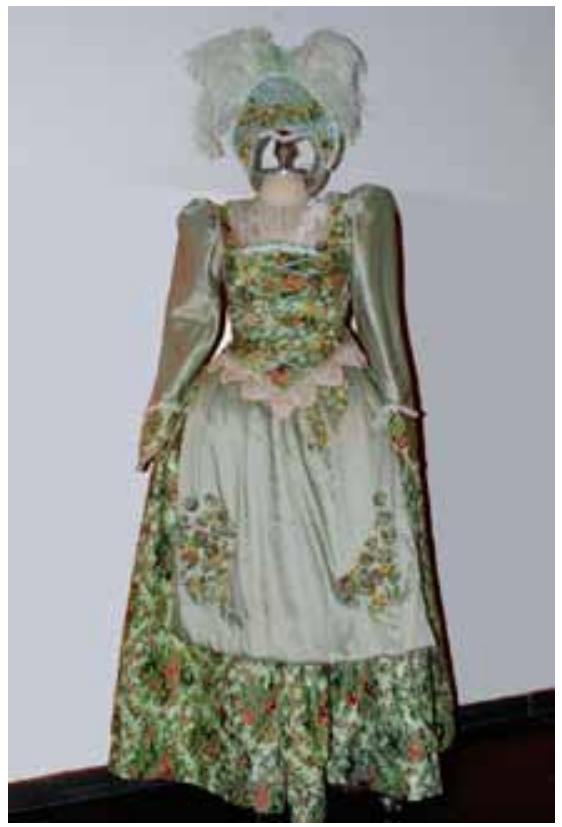

Figura 7: Figurino finalizado e completo de personagem feminino que representa o povo

Fonte: Mayra Castro e Priscilla Baetá.

(GRABURN, 1976, P. 16), sobretudo pelo alto grau de profissionais correlatos tanto à moda quanto ao figurino e ao carnaval nos espetáculos teatrais, produções televisivas e nos desfiles de escolas de samba e blocos carnavalescos. O entendimento de algumas questões aqui apresentadas pode modificar a visão de educadores sobre a festa carnavalesca e os produtos gerados a partir de sua preparação.

\section{REFERÊNCIAS BIBLIOGRÁFICAS}

BARBIERI, Ricardo José de Oliveira. Para brilhar na Sapucaí: hierarquia e liminaridade entre as escolas de samba. In Textos Escolhidos de Cultura e Arte Populares. Rio de Janeiro: UERJ/Instituto de Artes, 2010..

BECKER, Howard S. Mundos artísticos e tipos sociais. In VELHO, Gilberto (org.). Arte e sociedade: ensaios de sociologia da arte. Rio de Janeiro: Zahar, 1977.

BOMFIM, Gustavo Amarante. Ideias e formas na história do design: uma investigação estética. João Pessoa: Universitária, 1998.

CAVALCANTI, Maria Laura Viveiro de Castro. Festa e contravenção: os bicheiros no carnaval do Rio de Janeiro. In CAVALCANTI, Maria Laura e GONÇALVES, Renata (Orgs.). Carnaval em múltiplos planos. Rio de Janeiro: Aeroplano, 2009.

CIVITA, Victor. Mestres da pintura: Brueghel. São Paulo: Abril Cultural, 1978.

FARIAS, Júlio Cesar. Comissão de frente: alegria e beleza pedem passagem. Rio de Janeiro: Literis Ed., 2009.

FERREIRA, Felipe. O marquês e o jegue: estudo das fantasias para escolas de samba. Rio de Janeiro: Altos da Glória, 1999.

GOLDWASSER, Maria Julia. O palácio do samba: estudo antropológico da Escola de Samba Estação Primeira de Mangueira. Rio de Janeiro: Zahar, 1975. 
GRABURN, Nelson. Ethnic and tourist arts: cultural expressions from the Fourth World. Berkeley: University of California, 1976.

KÖHLER, Carl. História do vestuário. São Paulo: Martins Fontes, 1989.

LAVER, James. A roupa e a moda: uma história concisa. São Paulo: Companhia das Letras, 1989.

MAGALHÃES, Rosa Lúcia Benedetti. Fazendo carnaval: The making of carnival. Rio de Janeiro: Nova Aguilar, 1997.

OLIVEIRA, Madson L. G. de. Imaginários da criação: o tempo e o espaço dos souvenirs carnavalescos. Rio de Janeiro: PUC-Rio (Tese de Doutorado), 2010.

SABINO, Marco. Dicionário da moda. Rio de Janeiro: Elsevier, 2007.

SANTOS, Nilton Silva dos. Estilo autoral e individualidade artística: os carnavalescos no carnaval. In CAVALCANTI, Maria Laura e GONÇALVES, Renata (orgs.). Carnaval em múltiplos planos. Rio de Janeiro: Aeroplano, 2009.

SOMMERMAN, Américo. Inter ou transdisciplinaridade?: da fragmentação disciplinar ao novo diálogo entre os saberes. São Paulo: Paullus, 2006.

Madson Luis Gomes de Oliveira é doutor em design pelo Programa de Pós-Graduação em Design da PUC-Rio e professor adjunto do Curso de Artes Cênicas/Indumentária UFRJ/EBA.

Suely Medeiros Gerhardt é especialista em ensino da arte (Universidade Veiga de Almeida-UVA) e professora da área de criação e modelagem para os cursos de graduação da área de design e pós-graduação em figurino e carnaval, ambos na UVA. 